\title{
Хірургічна тактика при закритій абдомінальній травмі 3 пошкодженням брижі тонкого кишечника
}

\author{
V. V. MISHCHENKO, P. I. PUSTOVOIT, V. V. HORIACHYI \\ Odesa Regional Clinical Hospital
}

\section{SURGICAL TACTICS AT OCCLUDED OF THE ABDOMINAL TRAUMA WITH DAMAGE MESENTERIUM OF SMALL INTESTINES}

\begin{abstract}
Абдомінальна травма складає до 30 \% усіх травм. Метою нашого повідомлення було показати на прикладі клінічного спостереження нестандартний підхід при виборі алгоритму діагностично-лікувального напрямку у даної категорії хворих. Проведено клінічний розбір випадку закритої абдомінальної травми. Нестандартний підхід у даному випадку полягав в утрудненій діагностиці закритої абдомінальної травми, що призвело до втрати часу надання екстреної хірургічної допомоги, у виборі хірургічної тактики, яка полягала у накладанні кінцевої ілеостомії та санації черевної порожнини, а на відновному етапі - у накладанні латеро-латерального анастомозу між занадто коротким дистальним та проксимальним відділом здухвинної кишки, що дозволило запобігти необхідності виконання правосторонньої геміколектомії.

The abdominal trauma compounds to $30 \%$ of all traumas. The purpose of our report was to show on an example of clinical supervision the non-standard approach at a choice of diagnostico-medical algorithm in the yielded category of patients. Clinical analysis of a case occluded abdominal trauma was done. The Non-standard approach in this case consisted in complicated diagnostics occluded abdominal trauma that has led to loss of time of granting of the emergency surgical help, in a choice of surgical tactics which consisted in superposition final ileostomy and sanitation of a belly lumen, and at the regenerative stage - in superposition latero-lateral anastomosis between too short distal and proximal departments ileum intestines that has allowed to avoid necessity of performance right-hand hemicolectomy.
\end{abstract}

Абдомінальна травма (АТ) залишається актуальною проблемою в ургентній хірургії, складаючи до 30 \% усіх травм із летальністю до 27-47,6 \%, оскільки значну частину таких хворих госпіталізують за ургентними показаннями в загальнохірургічний стаціонар. Основною причиною смерті у 51,4 \% випадків є шок, у 13,8 \% - кровотеча. Клінічні прояви АТ не завжди дозволяють встановити правильний діагноз та визначити єдино правильну тактику надання допомоги. Відсутність конкретного алгоритму дій для ургентної бригади під час чергування утруднює ранню діагностику пошкоджень при АТ, зумовлює збільшення тривалості доопераційного періоду, впливає на подальшу хірургічну тактику та вибір методу лікування.

Метою нашого повідомлення було показати на прикладі клінічного спостереження нестандартний підхід при виборі алгоритму діагностично-лікувального напрямку в даної категорії хворих.

Хворий О. віком 49 років захворів гостро о $01^{\text {оо }}$ 13.12.12 р. після погрішності в дієті і фізичного на- вантаження 3 підняттям вантажу зі скаргами на розлитий біль у животі, здуття, нудоту, блювання, різко виражену слабість, задишку. Хворий був госпіталізований до хірургічного відділення ЦРЛ через 8 год, де після клініко-лабораторного та інструментального дослідження встановлено діагноз: "Гострий панкреатит, панкреонекроз. Розшаровуюча аневризма черевного відділу аорти?"

Через 17 год у зв'язку з погіршенням стану переведений до відділення інтенсивної терапії Одеської обласної клінічної лікарні у вкрай тяжкому стані $з$ діагнозом гострого панкреатиту. Параколічний інфільтрат. Кишкова непрохідність. Олігурія. При госпіталізації АТ - 110/70 мм рт. ст., сатурація кисню- 94 \%, П-103 уд/1 хв, ЧД- 22 за 1 хв, $\mathrm{t}-36,6^{\circ} \mathrm{C}$. Загальний аналіз крові: лейкоцити - 12,8×109/л, еритроцити $-4,0 \times 10^{12} /$ л, Нb - 133 г/л, тромбоцити $299 \times 10^{3} /$ л. На оглядовій рентгенограмі органів черевної порожнини у мезогастрії одиничні чашки Клойбера. Вільного газу не виявлено. Язик вологий, 3 
білим нальотом. Живіт роздутий, хворобливий скрізь, iз сумнівними ознаками перитоніту та наявністю параколічного інфільтрату по правому фланку. Хворому призначено: реосорбілакт - 400,0 , розчин глюкози $5 \% 400,0+$ розчин хлористого калію $3 \% 60,0$; розчин хлористого натрію $0,9 \% 400,0+$ контривен 100000 од; розчин Рінгера 200,0 внутрішньовенно краплинно; квамател 40 мг $\times 2$ рази внутрішньовенно; омез 40 мг $\times 2$ рази внутрішньовенно; метаклопрамід $2,0 \times 3$ рази внутрішньом'язово; цефтриаксон $1,0 \times 2$ рази внутрішньовенно; левофлокс 500 мг внугрішньовенно; прозерин 0,5 внутрішньом'язово; дигоксин $0,025 \% 1,0$ внутрішньовенно; фуросемід $1,0 \times 3$ рази внутрішньовенно.

Через 7 год після госпіталізації внаслідок проведеного консиліуму у хворого діагностовано розлитий перитоніт з вираженою інтоксикацією. За життєвими показаннями хворому виконано операцію: лапаротомію, резекцію здухвинної кишки, ілеостомію, санацію і дренування черевної порожнини.

Під час операційного втручання у черевній порожнині виявлено близько 500,0 мутного геморагічного ексудату. На відстані 10 см від сліпої кишки і проксимально здухвинна кишка відірвана від брижі на протязі 80 см, темно-багрового, а у кількох місцях - чорного кольору. Судини відірваної брижі тромбовані, ознак триваючої кровотечі не виявлено. У межах здорових тканин, відступивши $20 \mathrm{~cm}$ проксимальніше і на 8 см від сліпої кишки, де здухвинна кишка рожевого кольору, виконано резекцію некротизованої здухвинної кишки. Залишений дистальний відрізок здухвинної кишки заглушений, а проксимальний виведений на передню черевну стінку у вигляді кінцевої ілеостоми. Інших пошкоджень не виявлено. Черевну порожнину промито розчином декасану, просушено, дреновано поліхлорвініловими трубками у малий таз, фланки, під діафрагму з обох сторін.

Післяопераційний період перебігав тяжко. На 19-ту добу після операції хворий виписаний із стаціонару під нагляд хірурга за місцем проживання.

Через місяць госпіталізований у хірургічне відділення Одеської обласної клінічної лікарні для відновної операції. Після відповідної передопераційної підготовки та клініко-лабораторного й інструмен-

\section{СПИСОК ЛІТЕРАТУРИ}

1. Огнестрельные поражения легких / В. В. Бойко, В. В. Макаров, А. В. Токарев [и др.] // Український журнал хірургії. 2011. - № 2 (11). - C. 200-203.

2. Пеев С. Б. Обоснование применения малоинвазивных технологий при изолированной травме желудочно-кишечного тракта / С. Б. Пеев, В. В. Бойко, П. Н. Замятин // Вісник Україн- тального обстеження хворий був оперований. Операційний доступ - середньо-серединна лапаротомія під багатокомпонентним ендотрахеальним наркозом. У черевній порожнині виражений злуковий процес. Із технічними труднощами із злукового процесу виділено сліпу кишку, ідентифіковано заглушений термінальний кінець здухвинної кишки довжиною 5 cм, життєспроможний, 3 достатньо вираженим кровопостачанням. Кінцеву ілеостому видалено. Проведено резекцію термінального відділу проксимального кінця здухвинної кишки з його зашиванням двома напівкисетними та вузловими швами. Накладено ентеро-ентероанастомоз між дистальною та проксимальною частиною здухвинної кишки “бік у бік” 3 ушиванням вікна у брижі. До місця анастомозу підведено два трубчастих дренажі, які виведені у правій здухвинній ділянці. Операційна рана та рана після ілеостоми пошарово зашиті.

У післяопераційному періоді хворий одержував антибіотики, інфузійну терапію з препаратами, які покращують гемодинаміку в зоні накладеного анастомозу (актовегін 10,0 внутрішньовенно, трентал 5,0 внутрішньовенно упродовж 7 діб). Профілактику тромботичних ускладнень проводили введенням у підшкірну клітковину передньої черевної стінки еноксапарину натрію 0,2 1-2 рази на добу протягом 7 діб. Післяопераційний період перебігав без ускладнень. Перистальтика з'явилась на третю добу після операції, тоді ж розпочато ентеральне зондове харчування берламін-модуляром. Пасаж кишкового вмісту проконтрольовано за допомогою рентгенологічного дослідження з барієвою сумішшю. Ознак кишкової непрохідності, недостатності накладеного анастомозу та баугінієвої заслінки не виявлено.

Висновки. Нестандартний підхід у даному випадку полягав в утрудненій діагностиці закритої абдомінальної травми, що призвело до втрати часу надання екстреної хірургічної допомоги, у виборі хірургічної тактики, яка полягала в накладанні кінцевої ілеостомії та санації черевної порожнини, а на відновному етапі - у накладанні латеро-латерального анастомозу між занадто коротким дистальним та проксимальним відділом здухвинної кишки, що дозволило запобігти необхідності виконання правосторонньої геміколектомії.

ської медичної стоматологічної академії. - 2011. - Т. 11, вип. 1 (33). - С. 238-240.

3. Травматические повреждения двенадцатиперстной кишки / И. А. Криворучко, С. Н. Тесленко, А. В. Сивожелезов [и др.] // Український журнал хірургії. - 2011. - № 3 (12). - С. 41-46.

Отримано 27.01.15 